\title{
Assessment of Liver Functions Parameters of Asymptomatic Apparently Healthy Hepatitis B Virus Carriers among Voluntary Blood Donors in Some Parts of Nigeria

\author{
Kingsley Odiabara ${ }^{1 *}$, Ebirien-Agana Samuel Bartimaeus ${ }^{2}$, Edna O. Nwachuku ${ }^{3}$, Ndokiari Boisa $^{4}$
}

\author{
${ }^{1}$ Department of Laboratory Services and Quality, National Blood Service Commission, Abuja \\ ${ }^{2,3}$ Department of Medical Laboratory Science, Rivers State University, Nkpolu-Oroworukwo Port Harcourt, Nigeria \\ ${ }^{4}$ Department of Chemistry, Rivers State University, Nkpolu-Oroworukwo Port Harcourt, Nigeria
}

DOI: $10.36347 /$ sjams.2022.v10i01.006

| Received: 01.12.2021 | Accepted: 03.01.2022 | Published: 12.01.2022

*Corresponding author: Kingsley Odiabara

Department of Laboratory Services and Quality, National Blood Service Commission, Abuja

Abstract

Review Article

\begin{abstract}
Several studies have been conducted on hepatitis B virus and its manifestations including its effect on organ functions. Hepatitis B virus is a hepatotropic virus which courses inflammations of the liver and other complications such as cirrhosis, hepatocellular carcinoma, liver failure and death, this study assessed the effect of hepatitis B virus on liver functions in asymptomatic blood donors in some towns within three (3) geo-political zones in Nigeria. Method: A total of 183 subjects consisting of 137 males and 46 females participated in the North Central geopolitical zone: 176 subjects consisting of 129 males and 47 females participated in the North East, while 173 subjects consisting of 123 males and females participated in the South South Zone. The mean age of the subjects were $34.89{ }_{-}^{+} 9.19$ years for the three zones respectively. Blood sample were collected from the subjects and tested for Hepatitis B surface antigen (HBsAg) and also Human Immunodeficiency Virus (HIV) and Hepatitis C Virus (HCV) to rule out co-infection using ELISA. All samples were analysed for liver function parameter such as Total bilirubin, conjugated bilirubin, total protein, Albumin, Aspartate Aminotransferase (AST), Alannie Aminotransferase (ALT) and Alkaline Phosphatase (ALP), using Chemwell 2910 fully Automated chemistry analyser. The results were analysed using statistical analysis system (SAS, STAT 15.1), and p values < 0.05 were considered as statistically significant. Results: The mean values of total protein, albumin total bilirubin, conjugated bilirubin aspirant aminotransferase (AST \& ALT) and alkaline phosphate (ALP) did not vary significantly (P 005) between the hepatitis B virus negative and hepatitis B virus positive subjects across the geopolitical zones studied. However, the variation of alanine aminotransferase (ALT) was significant $(\mathrm{p}>0.014)$ between the two treatment groups across the three geopolitical zones, but the margin was not wide enough to draw clinical interference. The mean age of the study population was $34.89 \pm 9.19 ; 39.81 \pm 9.60$ and $49.92 \pm 9.27$ years in North Central, North East and South-South geopolitical zones respectively. The study observed that more males donate blood than females. The study also demonstrated higher prevalence rates of hepatitis B virus seropositivity in males than in females. On the basis of age groups (35-44) years recorded highest prevalence rates of hepatitis B virus seropositivity in the three zones. The assessment of liver function parameters did not reveal any altered pattern of their plasma levels except only ALT which shows significant difference at $\mathrm{P}<0.0140$. Apparently the HBV positive subjects were healthy.

Keywords: Liver Functions, Parameters of Asymptomatic.

Copyright $\odot \mathbf{2 0 2 2}$ The Author(s): This is an open-access article distributed under the terms of the Creative Commons Attribution 4.0 International License (CC BY-NC 4.0) which permits unrestricted use, distribution, and reproduction in any medium for non-commercial use provided the original author and source are credited.
\end{abstract}

\section{INTRODUCTION}

The liver is the largest organ in the body and it carries out several important functions such as metabolism of carbohydrates, fats and proteins, storage of glycogen, vitamins and minerals, production and excretion of bile, synthesis of plasma proteins, biotransformation of drugs and toxic substances [12].
It also catabolizes thyroid hormones, cortisol and vitamin D while it produces insulin-like-growth factor and angiotensinogen [12].

These functions of the liver expose it to several insults including viral agents. Hepatitis B virus is a DNA virus which attacks the liver resulting into inflammatory conditions [12]. It belongs to the hepadna 
family and it has high prevalence rates in Asia and SubSahara Africa. Its attendant morbidity and mortality rank among the most common human pathologies of great public health challenge $[34,25]$.

About two hundred and forty million persons are infected worldwide [25] while estimated deaths arising from complications of hepatitis B virus infection is put at two hundred and fifty thousand annually [18].

The virus is transmitted through exposure with body fluids, such as blood, seminal fluid and vaginal secretions of an infected person [29]. It has longer incubation period of between 50 and 180 days and the virus can survive at surfaces for about a week [1, 15, 16].

The primary target organ of the hepatitis B virus is the liver resulting in hepatitis which could be acute or chronic. The acute hepatitis infection is of short duration usually less than 6 months and it is clinically cleared following development of natural antibodies $[12,13]$.

The chronic phase last longer than six (6) months and could cause serious inflammatory and destructive disease of the liver [17], which progresses with time to complications such as liver cirrhosis, hepatocellular carcinoma and death [17, 31, 21]. The clinical outcome in both acute and chronic cases is strongly dictated by age and immune state of the patient [34].

Treatment can slow progressing of the disease, complications and increase chances of survival. These benefits of treatment are consistent with the recommended treatment goals of World Health Organization [34], American Association for Study of Liver Disease [33] and Guidelines for prevention, treatment and care of viral hepatitis in Nigeria [14].

The prevention of hepatis B virus infection by vaccination is the main strategy to eradicate $\mathrm{HBV}$ [7]. The vaccine contains HBsAg produced by recombinant DNA techniques from yeast [17] and it provides longterm immunity.

The virus can be diagnosed by the presence of a viral surface antigen (HBsAg), a core antigen and antibody to the surface antigen [8]. However, HBsAg is used to detect current infections in both acute and chronic cases [12].

Although many individuals survive, others develop complications and, in some cases, death may result [25]. The clinical outcome in both acute and chronic cases is strongly dictated by age and immune state of the patient. However, about 30 to $50 \%$ of adolescents and adults develop jaundice [12]. Symptoms of the infection may include high grade fever, joint and muscle pain, loss of appetite and stomach pain. Some patients may indicate bloated stomach, jaundice and nausea. Chronic hepatitis B infected individuals may develop liver inflammation, hepatocellular destruction leading to cirrhosis and hepatocellular carcinoma [19].

On a rare frequency, fulminant hepatitis can occur with a new acute infection and the patient could suddenly develop liver failure, consequently, intravascular coagulation may occur. It has been shown that such patients also indicate cellular metabolic abnormalities [30].

Hepatitis B can be diagnosed by the presence of a viral surface antigen ( $\mathrm{HBsAg}$ ), a core antigen (HBeAg) and surface antibody (anti-HBsAg) [8]. HBsAg is used to detect current infections in both acute and chronic cases [12].

The safety and efficacy of blood products are primary concerns of transfusion medicines practitioners and blood transfusion services. Screening of prospective blood donors for infectious diseases consist of completing a standard pre-donation questionnaire, counselling and post-donation testing of donor samples by the blood service to detect transfusion transmissible infections such as HIV, HBV, HCV, and Syphilis [10].

Serological screening tests have proved to be useful and cost - effective tools in helping to keep the blood supply safe. However, the window period for antibody development could take several weeks after pathogen exposure, thus affecting its detection rate. Infact much of the residual transfusion - related transmission of HIV, HBV, and $\mathrm{HCV}$ is from seronegative donors within this window period.

Recipients of infected blood will sooner or later develop the infection if the immunologic system is not able to clear the virus early before it replicates tremendously in the body. In the case of hepatitis B virus, the liver will certainly receive the assault with attendant consequences. Biochemical measurements particularly of plasma total proteins, albumin, bilirubin, aminotransferase enzymes and alkaline phosphatase could play a role in the discovery that liver damage has occurred and also in monitoring therapeutic progress [5].

This study assessed the effect of hepatitis B virus on liver function parameters in asymptomatic carriers among voluntary blood donors in some towns in Nigeria.

\section{Characteristics of the Subjects}

The subjects were prospective blood donors who visited the National Blood Transfusion Service Centres, to donate blood on the basis of voluntary donation. They were mainly persons who met the 
Kingsley Odiabara et al; Sch J App Med Sci, Jan, 2022; 10(1): 34-45

inclusion criteria of age, weight, haemoglobin level and health check and were considered fit to donate blood after physical examination and counselling. Those who were differed from donating blood were excluded from the study.

\section{Ethical Approval and informed consent by the subjects}

Ethical approval was obtained from the National Health Research Ethics Committee. Approval was also obtained from the National Blood Transfusion Service headquarter to use its platform to recruit voluntary blood donors for the study.

Informed consent was obtained from the subject after thorough explanation of the purpose, benefits and risk of the study. Participants who declined to participate in the study were excluded.

\section{Sample Size Calculation}

The sample size for the study was determined using the formula for cross sectional studies [6]. The study sample size required from each geopolitical zone was 150 subjects.

\subsection{COLLECTION OF BLOOD SPECIMEN}

Blood specimen was collected from the study subject after donating a unit of blood into EDTA specimen containers. Blood specimen was again collected from the subjects into Lithium Heparin sample containers. The EDTA specimen was centrifuged and the plasma was used in the determination of hepatitis B surface antigen, hepatitis C and Human Immunodeficiency Virus antigen-antibodies using Enzyme linked immunosorbent assay technique (ELISA). The assay is a qualitative one-step enzyme immunoassay technique of sandwich type for the detection of HBsAg in human serum or plasma and it is intended for screening of blood donations and for diagnostics [3]. The Lithium Heparin sample was also centrifuged and the plasma was used in analysis of liver function parameters-total protein, albumin, total bilirubin, conjugated bilirubin AST and ALP.

\section{Testing of the Samples}

The plasma samples were analysed for hepatitis B surface antigen, hepatitis C antibody and human immunodeficiency virus at the National Blood Transfusion Service Laboratory in Abuja. The screening for hepatitis $\mathrm{C}$ and HIV was aimed at rulingoff any co-infection [3, 11].

\section{Determination of Liver Function Parameters}

Liver Function Parameters were determined using a Chem-well ${ }^{(\mathrm{R})} \mathrm{T}$-Automated Chemistry Analyzer, produced by awareness Technology Inc., USA. The Chem-well ${ }^{(\mathrm{R})} \mathrm{T}$ is fully automated open system analyser for biochemistry assays and is supplied with optimized programmed protocols ready for use with an extensive range of megazyme test kits. All the reagent and serum samples were left out to adjust to the room prior to analyses [2].

\section{Statistical Analysis}

The results were analysed using Statistical Analysis System (SAS). STAT 15.1 developed by SAS Institute, North Carolina State University, USA. Data were presented as mean \pm SEM, comparison of groups that were more than two was done using one-way analysis of variance (ANOVA) and the Turkey test of multiple comparisons was used to test for variance across groups. Variations in means of parameters were considered statistically significant at $\mathrm{p}<0.05$.

\section{RESULTS}

\section{Sociodemographic Characteristics of the Study Population}

A total of 532 subjects who are voluntary nonremunerated blood donors participated in the study. The North Central geographical zone had183 participants whose mean age was $34.89+-9.19$ years out of which 154 (84.15\% were negative to hepatitis B virus (HBsAg) while 29 (15.85\%) were positive. The North East geographical zone had 176 participants whose mean age was $39.81+-9.60$ years out of which $156(88.64 \%)$ were negative to HBV while $20(11.36 \%)$ were positive while the South-South geographical zone had 173 participants whose mean age was $39.81 \pm 27$ years out of which $153(88.44 \%)$ were negative to HBV while 20 were positive. (61.75) were males with mean age $41.91 \pm 9.25$ years, while 41 were females with mean age of $35.29 \pm 9.52$ years. In the North East geographical zone male HBV negative subjects were $42(23.86 \%)$ with mean age of $28.05 \pm 6.10$ years.

In the South-South geographical zone male HBV negative subjects were $109(63.010 \%)$ with mean age of $43.41 \pm 8.13$ years while females were 44 $(22.43 \%)$ with mean age of $31.41 \pm 7.55$ years.

On the other hand, 29 (15.85\%) subjects were HBV positive in the North Central geographical zone among whom $24(13.11 \%)$ males with mean age of $39.42 \pm 5.52$ years and $5(2.73 \%)$ females with mean age of $31.60 \pm 5,32$ years.

The North East geographical zone had 20 $(11.36 \%) \mathrm{HBV}$ positive subjects out of which 15 $(8.52 \%)$ were males with mean age of $42.13 \pm 4.07$ years and $5(2.84 \%)$ females with mean age of $33.40 \pm$ 2.61 years.

In the South-South geographical zone, HBV positive subjects were $20(11.56 \%)$ comprising of 14 $(8.09 \%)$ with mean age of $42.00 \pm 3.59$ years and $6(3.47 \%)$ females with mean age of $33.67 \pm 7.15$ years.

The aggregate prevalence rate of $\mathrm{HBV}$ (HBsAg) negative in the three geopolitical zones by sex 
Kingsley Odiabara et al; Sch J App Med Sci, Jan, 2022; 10(1): 34-45

was $63.16 \%$ for males and $23.87 \%$ for females, while the prevalence rate of $\mathrm{HBsAg}$ positive was $9.96 \%$ for males and $3.01 \%$ for females.
However, the overall prevalence rate of HBsAg in the study population was $12.97 \%$ (Table 1).

Table-1.1: Sociodemographic Characteristics of the Study Population

\begin{tabular}{|c|c|c|c|c|c|c|c|c|c|}
\hline \multirow{4}{*}{ Characteristic } & \multirow{4}{*}{$\mathbf{N}(\%)$} & \multicolumn{8}{|c|}{ Treatment Groups } \\
\hline & & \multicolumn{4}{|c|}{ Hepatitis Negative } & \multicolumn{4}{|c|}{ Hepatitis Positive } \\
\hline & & \multicolumn{2}{|c|}{ Male } & \multicolumn{2}{|c|}{ Female } & \multicolumn{2}{|c|}{ Male } & \multicolumn{2}{|c|}{ Female } \\
\hline & & $\mathbf{N}$ & $\%$ & $\mathbf{N}$ & $\%$ & $\mathbf{N}$ & $\%$ & $\mathbf{N}$ & $\%$ \\
\hline North Central & $183(100)$ & 113 & 73.38 & 41 & 26.62 & 24 & 82.76 & 5 & 17.24 \\
\hline $\begin{array}{l}\text { Age Group (yrs) } \\
<25 \\
25-34 \\
35-44 \\
45-54 \\
55+ \\
\end{array}$ & $\begin{array}{l}12(6.56) \\
31(16.94) \\
91(49.73) \\
36(19.67) \\
13(7.10)\end{array}$ & $\begin{array}{l}6 \\
12 \\
56 \\
28 \\
11 \\
\end{array}$ & $\begin{array}{l}3.90 \\
7.79 \\
36.36 \\
18.18 \\
7.14 \\
\end{array}$ & $\begin{array}{l}5 \\
14 \\
15 \\
5 \\
2 \\
\end{array}$ & $\begin{array}{l}3.25 \\
9.09 \\
9.74 \\
3.25 \\
1.30 \\
\end{array}$ & $\begin{array}{l}1 \\
1 \\
19 \\
3 \\
---\end{array}$ & $\begin{array}{l}3.45 \\
3.45 \\
65.52 \\
10.34 \\
-- \\
\end{array}$ & $\begin{array}{l}0 \\
4 \\
1 \\
0 \\
--- \\
\end{array}$ & $\begin{array}{l}0.00 \\
13.79 \\
3.45 \\
0.00 \\
--- \\
\end{array}$ \\
\hline Age $($ Mean \pm SD $)$ & $34.89 \pm 9.19$ & \multicolumn{2}{|c|}{$41.91 \pm 9.25$} & \multicolumn{2}{|c|}{$35.29 \pm 9.52$} & \multicolumn{2}{|c|}{$39.42 \pm 5.52$} & \multicolumn{2}{|c|}{$31.60 \pm 5.32$} \\
\hline North East & $176(100)$ & 114 & 73.08 & 42 & 26.92 & 15 & 75.00 & 5 & 25.00 \\
\hline $\begin{array}{l}\text { Age group (yrs) } \\
<25 \\
25-34 \\
35-44 \\
45-54 \\
55+\end{array}$ & $\begin{array}{l}16(9.09) \\
33(18.75) \\
65(36.93) \\
52(29.55) \\
10(5.68)\end{array}$ & $\begin{array}{l}1 \\
9 \\
46 \\
48 \\
10 \\
\end{array}$ & $\begin{array}{l}0.64 \\
5.77 \\
29.49 \\
30.77 \\
6.41 \\
\end{array}$ & $\begin{array}{l}15 \\
20 \\
7 \\
0 \\
0\end{array}$ & $\begin{array}{l}9.62 \\
12.82 \\
4.49 \\
0.00 \\
0.00\end{array}$ & $\begin{array}{l}--- \\
1 \\
10 \\
4 \\
---\end{array}$ & $\begin{array}{l}--- \\
5.00 \\
50.00 \\
20.00 \\
---\end{array}$ & $\begin{array}{l}--- \\
3 \\
2 \\
0 \\
---\end{array}$ & $\begin{array}{l}--- \\
15.00 \\
10.00 \\
0.00 \\
---\end{array}$ \\
\hline Age $($ Mean \pm SD) & $39.81 \pm 9.60$ & \multicolumn{2}{|c|}{$44.12 \pm 7.35$} & \multicolumn{2}{|c|}{$28.05 \pm 6.10$} & \multicolumn{2}{|c|}{$42.13 \pm 4.07$} & \multicolumn{2}{|c|}{$33.40 \pm 2.61$} \\
\hline South-South & $173(100)$ & 109 & 71.24 & 44 & 28.76 & 14 & 70.00 & 6 & 30.00 \\
\hline $\begin{array}{l}\text { Age group }(\text { yrs }) \\
<25 \\
25-34 \\
35-44 \\
45-54 \\
55+\end{array}$ & $\begin{array}{l}17(9.83) \\
27(15.61) \\
74(42.78) \\
48(27.75 \\
7(4.05)\end{array}$ & $\begin{array}{l}6 \\
6 \\
48 \\
42 \\
7 \\
\end{array}$ & $\begin{array}{l}3.92 \\
3.92 \\
31.37 \\
27.45 \\
4.58 \\
\end{array}$ & $\begin{array}{l}10 \\
18 \\
14 \\
2 \\
0\end{array}$ & $\begin{array}{l}6.54 \\
11.76 \\
9.15 \\
1.31 \\
0.00\end{array}$ & $\begin{array}{l}0 \\
0 \\
11 \\
3 \\
---\end{array}$ & $\begin{array}{l}0.00 \\
0.00 \\
55.00 \\
15.00 \\
---\end{array}$ & $\begin{array}{l}1 \\
3 \\
1 \\
1 \\
---\end{array}$ & $\begin{array}{l}5.00 \\
15.00 \\
5.00 \\
5.00 \\
---\end{array}$ \\
\hline Age $($ Mean \pm SD $)$ & $39.92 \pm 9.27$ & \multicolumn{2}{|c|}{$43.41 \pm 8.13$} & \multicolumn{2}{|c|}{$31.45 \pm 7.55$} & \multicolumn{2}{|c|}{\begin{tabular}{|l|l|}
-- & -- \\
$42.00 \pm 3.59$
\end{tabular}} & \multicolumn{2}{|c|}{$33.67 \pm 7.15$} \\
\hline
\end{tabular}

Note: Percentages may not add up to exactly 100 due to rounding up.

\section{Liver Function Parameters of the study population} The liver function parameters of the study subject in the geopolitical zones in the HBsAg negative and positive by hepatitis B status and sex subjects is shown in tables 2 (a) and 2 (b).

\section{Total Bilirubin among HBsAg Negative and Positive participants in the Geo-Political Zones}

In the North Central zone, mean levels of total bilirubin for male $\mathrm{HBsAg}$ negative participants was $16.90 \pm 0.71 \mu \mathrm{mol} / 1$, while mean plasma levels for total bilirubin in the female participants $14.58 \pm 1.17 \mu \mathrm{mol} / \mathrm{L}$. Correspondingly, among HBsAg positive participants in the North Central geopolitical zone, the mean plasma levels of total bilirubin in the male participants was $15.59 \pm 1.52 \mu \mathrm{mol} / \mathrm{l}$, while mean plasma total bilirubin in the female participants $10.20 \pm 3.34 \mu \mathrm{mol} / \mathrm{l}$.

In the North East zone, mean plasma levels of total bilirubin in male HBsAg negative participants was $12.81 \pm 0.70 \mu \mathrm{mol} / 1$, while mean plasma levels of total bilirubin in the female participants was $13.77 \pm 1.15 \mu \mathrm{mol} / \mathrm{l}$. The mean plasma total bilirubin in the male HBsAg positive participants was $16.07 \pm 1.93$ $\mu \mathrm{mol} / \mathrm{l}$, while mean plasma total bilirubin in the female participants was $14.34 \pm 3.34 \mu \mathrm{mol} / 1$.

In the South-South zone, mean plasma levels of total bilirubin in male $\mathrm{HBsAg}$ negative participants was $13.02 \pm 0.72 \mu \mathrm{mol} / 1$, while the value in the female participants was $11.07 \pm 1.13 \mu \mathrm{mol} / \mathrm{l}$. Similarly, the mean plasma total bilirubin in the male $\mathrm{HBsAg}$ positive participants was $14.57 \pm 2.00 \mu \mathrm{mol} / \mathrm{l}$, while mean levels for female participants was $12.41 \pm 3.05 \mu \mathrm{mol} / \mathrm{l}$. The comparison of the means of total bilirubin across the three geopolitical zones by HBsAg status and sex did not show any significance $(\mathrm{F}=0.1583, \mathrm{P}=0.8536)$. The boxplot of the distribution of the mean of total bilirubin across the three geopolitical zones by HBsAg status and sex is shown in Figure 1.

\section{Conjugated Bilirubin among HBsAg Negative Participants in the Geo-Political Zones}

In the North Central zone, mean levels of conjugated bilirubin for male HBsAg negative subjects was $4.36 \pm 0.25 \mu \mathrm{mol} / 1$, while mean levels in the female subjects was $3.62 \pm 0.25 \mu \mathrm{mol} / \mathrm{L}$. Conversely, among HBsAg positive subjects in the North Central geopolitical zone, mean conjugated bilirubin level in 
Kingsley Odiabara et al; Sch J App Med Sci, Jan, 2022; 10(1): 34-45

male subjects was $5.05 \pm 0.53 \mu \mathrm{mol} / 1$, while mean levels in the female subjects was $3.06 \pm 1.16 \mu \mathrm{mol} / \mathrm{L}$.

In the North-East zone, mean conjugated bilirubin level in male HBsAg negative subjects was $3.36 \pm 0.24 \mu \mathrm{mol} / 1$, while the mean level in the female subjects was $2.88 \pm 0.40 \mu \mathrm{mol} / \mathrm{L}$. The mean conjugated bilirubin levels in male $\mathrm{HBsAg}$ positive subjects was $5.81 \pm 0.67 \mu \mathrm{mol} / 1$, while the value in the female subjects was $3.14 \pm 1.16 \mu \mathrm{mol} / 1$.

In South-South zone, mean conjugated bilirubin levels in male HBsAg negative subjects was $4.52 \pm 0.2 \mu \mathrm{mol} / 1$, while mean levels in the female subjects was $3.98 \pm 0.39 \mu \mathrm{mol} / 1$. Whereas the mean conjugated bilirubin levels in male HBsAg positive subjects was $4.43 \pm 0.69 \mu \mathrm{mol} / 1$, the mean conjugated bilirubin levels in the female subjects was $3.50 \pm 1.06 \mu \mathrm{mol} / 1$. The comparison of conjugated bilirubin level in the three geopolitical zones disaggregated by HBsAg status and sex was not significant $(\mathrm{F}=0.4208, \mathrm{P}=0.6567)$. The boxplot of the distribution of conjugated bilirubin level in the three geopolitical zones disaggregated by $\mathrm{HBsAg}$ status and sex is shown in Figure 2.

\section{Total Protein Levels among HBsAg Negative and} Positive participants in the Geo-Political Zones

In the North Central zone, mean total protein level in male $\mathrm{HBsAg}$ negative subjects was $7.40 \pm 0.07 \mathrm{~g} / \mathrm{dl}$, while mean levels in the female subjects was $7.28 \pm 0.12 \mathrm{~g} / \mathrm{dl}$. Similarly, among $\mathrm{HBsAg}$ positive subjects in the North Central geopolitical zone, mean total protein level in male subjects was $7.43 \pm 0.15 \mathrm{~g} / \mathrm{dl}$, while mean total protein level in the female subjects was $7.34 \pm 0.33 \mathrm{~g} / \mathrm{dl}$.

In the North East zone, mean total protein levels in the male HBsAg negative subjects was $7.83 \pm 0.07 \mathrm{~g} / \mathrm{dl}$, while the mean levels in the female subjects was $7.76 \pm 0.11 \mathrm{~g} / \mathrm{dl}$. The mean total protein level in male HBsAg positive subjects was $8.25 \pm 0.19 \mathrm{~g} / \mathrm{dl}$, while mean level in the female subjects was $7.82 \pm 0.33 \mathrm{~g} / \mathrm{dl}$.

In the South-South zone, mean total protein level in male HBsAg negative subjects was $7.44 \pm 0.07 \mathrm{~g} / \mathrm{dl}$, while mean level in the female subjects was $7.25 \pm 0.11 \mathrm{~g} / \mathrm{dl}$. The mean total protein levels in the male HBsAg positive subjects was $7.54 \pm 0.20 \mathrm{~g} / \mathrm{dl}$, while the mean level in the female subjects was $6.85 \pm 0.33 \mathrm{~g} / \mathrm{dl}$. The comparison of total protein level in the three geopolitical zones disaggregated by $\mathrm{HBsAg}$ status and sex did not show any significance $(\mathrm{F}=0.4874$, $\mathrm{P}=0.6145)$. The boxplot of the distribution of total protein level in the three geopolitical zones disaggregated by HBsAg status and sex is shown in Figure 3.
Plasma Albumin Levels among HBsAg Negative and Positive Participants in the Geo-Political Zones

In the North Central zone, mean albumin level in male $\mathrm{HBsAg}$ negative participants was $3.55 \pm 0.05 \mathrm{~g} / \mathrm{dl}$, while the mean level in the female participants was $3.46 \pm 0.08 \mathrm{~g} / \mathrm{dl}$. Similarly, among HBsAg positive subjects in the North Central geopolitical zone, mean albumin level in the male subjects was $3.40 \pm 0.11 \mathrm{~g} / \mathrm{dl}$, while the mean albumin level in the female subjects was $3.64 \pm 0.24 \mathrm{~g} / \mathrm{dl}$.

In the North East zone, mean albumin level in the male $\mathrm{HBsAg}$ negative participants was $4.70 \pm 0.05 \mathrm{~g} / \mathrm{dl}$, while the albumin level in the female participants was $4.63 \pm 0.08 \mathrm{~g} / \mathrm{dl}$. The mean albumin level in the male HBsAg positive subjects was $4.56 \pm 0.14 \mathrm{~g} / \mathrm{dl}$, while mean albumin level in the female subjects was $4.34 \pm 0.24 \mathrm{~g} / \mathrm{dl}$.

In the South-South zone, mean albumin level in ma le HBsAg negative participants was $3.99 \pm 0.05 \mathrm{~g} / \mathrm{dl}$, while mean albumin level in the female participants was $3.88 \pm 0.08 \mathrm{~g} / \mathrm{dl}$. The mean albumin level in male HBsAg positive subjects was $3.79 \pm 0.14 \mathrm{~g} / \mathrm{dl}$, while the mean albumin level in the female subjects was $4.02 \pm 0.22 \mathrm{~g} / \mathrm{dl}$. The comparison of plasma albumin concentration in the three geopolitical zones disaggregated by $\mathrm{HBsAg}$ and sex did not show any significance $(\mathrm{F}=0.9126, \mathrm{P}=0.4041)$. The boxplot of the distribution of plasma albumin concentration in the three geopolitical zones disaggregated by HBsAg and sex is shown in Figure 4.

\section{AST Levels among HBsAg Negative Participants in the Geo-Political Zones}

In the North Central zone, mean AST level in the male $\mathrm{HBsAg}$ negative subjects was 26.16 \pm 1.11 $\mathrm{IU} / \mathrm{L}$, while the mean level in female subjects was 26.57 \pm 1.84 IU/L. Comparably, among HBsAg positive subjects in the North Central geopolitical zone, mean AST level in the male subjects was $32.54 \pm 2.41 \mathrm{IU} / \mathrm{L}$, while the mean AST level in the female subjects was 38.06 $\pm 5.28 \mathrm{IU} / \mathrm{L}$.

In the North East zone, mean AST levels in the HBsAg negative males was $26.19 \pm 1.10 \mathrm{IU} / \mathrm{L}$, while the mean level in the females was $24.29 \pm 1.82$ IU/L. The mean AST level in the male HBsAg positive subjects was $40.34 \pm 3.05 \mathrm{IU} / \mathrm{L}$, while mean AST level in the female subjects was $37.90 \pm 5.28 \mathrm{IU} / \mathrm{L}$.

In the South-South zone, the mean AST level in male $\mathrm{HBsAg}$ negative subjects was $27.10 \pm 1.13 \mathrm{IU} / \mathrm{L}$, while mean AST level in the female subjects was $24.54 \pm 1.78 \mathrm{U} / \mathrm{L}$. However, mean AST levels in male HBsAg positive subjects was 46.22 $\pm 3.15 \mathrm{IU} / \mathrm{L}$, while

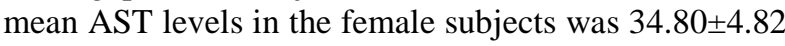
IU/L. The comparison of AST level in the three geopolitical zones disaggregated by $\mathrm{HBsAg}$ and sex did not show any significance $(\mathrm{F}=1.3043, \mathrm{P}=0.2723)$. The 
Kingsley Odiabara et al; Sch J App Med Sci, Jan, 2022; 10(1): 34-45

boxplot of the distribution of AST level in the three geopolitical zones disaggregated by HBsAg and sex is shown in Figure 5.

\section{ALT Level among HBsAg Negative and Positive Participants in the Geo-political Zones \\ In the North Central zone, the mean ALT level} in male HBsAg negative subjects was $26.33 \pm 1.48 \mathrm{IU} / \mathrm{L}$, while the mean ALT level in the female subjects was 22.42 \pm 2.45 IU/L. Conversely, among HBsAg positive subjects in the North Central geopolitical zone, mean ALT level in the male subjects was $41.83 \pm 3.201 \mathrm{IU} / \mathrm{L}$, while the mean ALT level in the female subjects was $52.80 \pm 7.01 \mathrm{IU} / \mathrm{L}$.

In the North East zone, mean ALT level in male HBsAg negative subjects was $27.52 \pm 1.47 \mathrm{IU} / \mathrm{L}$, while the value in the female subjects was $25.02 \pm 2.42$ IU/L. The mean ALT level in male HBsAg positive subjects was 64.81 $\pm 4.05 \mathrm{IU} / \mathrm{L}$, while mean ALT level in the female subjects was $64.84 \pm 7.01 \mathrm{IU} / \mathrm{L}$.

In the South-South zone, mean ALT level in male HBsAg negative subjects was $26.54 \pm 1.50 \mathrm{IU} / \mathrm{L}$, while mean ALT level in the female subjects was 23.50 $\pm 2.36 \mathrm{IU} / \mathrm{L}$. While mean ALT level in male HBsAg positive subjects was $69.06 \pm 4.19 \mathrm{IU} / \mathrm{L}$, mean level in the female subjects was $47.32 \pm 6.40 \mathrm{IU} / \mathrm{L}$. The comparison of ALT level in the geopolitical zones disaggregated by HBsAg status and sex was significant $(\mathrm{F}=4.3049, \mathrm{P}=0.0140)$. The boxplot of the distribution of ALT ALT level in the geopolitical zones disaggregated by HBsAg status and sex is shown in Figure 6.

\section{ALP Level among HBsAg Negative and Positive participants in the Geo-political Zones \\ In the North Central zone, mean ALP level in} male HBsAg negative participants was $81.33 \pm 3.17$ IU/L, while mean ALP levels in the female participants was $80.82 \pm 5.23$ IU/L. Similarly, among HBsAg positive participants in the North Central geopolitical zone, mean ALP level in male participants was 97.03 $\pm 6.84 \mathrm{IU} / \mathrm{L}$, whereas mean ALP level in the female subjects was $88.44 \pm 14.99$ IU/L.

In the North East zone, mean ALP level in male HBsAg negative participants was 107.65 \pm 3.17 IU/L, while mean ALP level in the female participants was $102.93 \pm 5.17$ IU/L. Ialso, mean ALP level in male HBsAg positive participants was $129.33 \pm 8.65 \mathrm{IU} / \mathrm{L}$, while mean ALP level in the female participants was $140.00 \pm 14.99 \mathrm{IU} / \mathrm{L}$.

In the South-South zone, mean ALP level in male HBsAg negative participants was 115.40 \pm 3.21 IU/L, while mean ALP levels in female participants was 115.42 \pm 5.05 IU/L. The mean ALP level in male HBsAg positive participants was $136.14 \pm 8.96 \mathrm{IU} / \mathrm{L}$, while mean ALP level in the female participants was $138.17 \pm 13.68$ IU/L. The comparison of ALP level in the geopolitical zones disaggregated by HBsAg status and sex did not show any significance $(\mathrm{F}=0.4286, \mathrm{P}=0.6517)$. The boxplot of the distribution of ALP level in the geopolitical zones disaggregated by HBsAg status and sex is shown in Figure 7.

Table-2(a): Liver Function Parameters of Volunteer Blood Donors by Geo-Political Zone, Hepatitis B Status and Sex (Mean \pm SEM)

\begin{tabular}{|l|l|l|l|l|l|l|}
\hline $\begin{array}{l}\text { Geo-Political } \\
\text { Zone }\end{array}$ & $\begin{array}{l}\text { Hepatitis B } \\
\text { Status }\end{array}$ & Sex & $\begin{array}{l}\text { TOT } \\
(\mu \mathrm{mol} / \mathbf{L})\end{array}$ & $\begin{array}{l}\text { CONJ. } \\
(\boldsymbol{\mu m o l} / \mathbf{L})\end{array}$ & $\begin{array}{l}\text { TOT. } \\
(\mathbf{g} / \mathbf{d L})\end{array}$ & $\begin{array}{l}\text { PROT } \\
(\mathbf{g} / \mathbf{L})\end{array}$ \\
\hline North Central & Negative & Female & $14.58 \pm 1.17$ & $3.62 \pm 0.41$ & $7.28 \pm 0.12$ & $3.46 \pm 0.08$ \\
\hline & Negative & Male & $16.90 \pm 0.71$ & $4.36 \pm 0.25$ & $7.40 \pm 0.07$ & $3.55 \pm 0.05$ \\
\hline & Positive & Female & $10.20 \pm 3.34$ & $3.06 \pm 1.16$ & $7.34 \uparrow 10.33$ & $3.64 \pm 0.24$ \\
\hline & Positive & Male & $15.59 \pm 1.52$ & $5.05 \pm 0.53$ & $7.43 \pm 0.15$ & $3.40 \pm 0.11$ \\
\hline North East & Negative & Female & $13.77 \pm 1.15$ & $2.88 \pm 0.40$ & $7.76 \pm 0.11$ & $4.63 \pm 0.08$ \\
\hline & Negative & Male & $12.81 \pm 0.70$ & $3.36 \pm 0.24$ & $7.83 \pm 0.07$ & $4.70 \pm 0.05$ \\
\hline & Positive & Female & $14.34 \pm 3.34$ & $3.14 \pm 1.16$ & $7.82 \pm 0.33$ & $4.34 \pm 0.24$ \\
\hline & Positive & Male & $16.07 \pm 1.93$ & $5.81 \pm 0.67$ & $8.25 \pm 0.19$ & $4.56 \pm 0.14$ \\
\hline South-South & Negative & Female & $11.07 \pm 1.13$ & $3.98 \pm 0.39$ & $7.25 \pm 0.11$ & $3.88 \pm 0.08$ \\
\hline & Negative & Male & $13.02 \pm 0.72$ & $4.52 \pm 0.25$ & $7.44 \pm 0.07$ & $3.99 \pm 0.05$ \\
\hline & Positive & Female & $12.41 \pm 3.05$ & $3.50 \pm 1.06$ & $6.85 \pm 0.30$ & $4.02 \pm 0.22$ \\
\hline & Positive & Male & $14.57 \pm 2.00$ & $4.43 \pm 0.69$ & $7.54 \pm 0.20$ & $3.79 \pm 0.14$ \\
\hline Test Statistic F-Ratio & & 0.1583 & 0.4208 & 0.4874 & 0.9126 \\
\hline P-value & & $0.8536^{\text {ns }}$ & $0.6567^{\text {ns }}$ & $0.6145^{\text {ns }}$ & $0.4021^{\text {ns }}$ \\
\hline
\end{tabular}

Significance Level: $n s=$ Not significant $(p>0.05)$, Tot. Bil = total bilirubin, Conj. Bil. $=$ conjugated bilirubin, Tot. Prot. $=$ total protein, Alb.= albumin. 
Kingsley Odiabara et al; Sch J App Med Sci, Jan, 2022; 10(1): 34-45

Table-2(b): Liver Function Parameters of Volunteer Blood Donors by Geo-Political Zone, Hepatitis B Status and Sex (Mean \pm

\begin{tabular}{|l|l|l|l|l|l|}
\hline Geo-Political Zone & $\begin{array}{l}\text { Hepatitis } \\
\text { Status }\end{array}$ & Sex & AST (IU/L) & ALT (IU/L) & ALP (IU/L) \\
\hline North Central & Negative & Female & $26.57 \pm 1.84$ & $22.42 \pm 2.45 \mathrm{a}$ & $80.82 \pm 5.23$ \\
\hline & Negative & Male & $26.16 \pm 1.11$ & $26.33 \pm 1.48 \mathrm{a}$ & $81.33 \pm 3.17$ \\
\hline & Positive & Female & $38.06 \pm 5.28$ & $52.80 \pm 7.01 \mathrm{~b}$ & $88.44 \pm 14.99$ \\
\hline & Positive & Male & $32.54 \pm 2.41$ & $41.83 \pm 3.20 \mathrm{c}$ & $97.03 \pm 6.84$ \\
\hline North East & Negative & Female & $24.29 \pm 1.82$ & $25.02 \pm 2.42$ a & $102.93 \pm 5.17$ \\
\hline & Negative & Male & $26.19 \pm 1.10$ & $27.52 \pm 1.47$ a & $107.65 \pm 3.14$ \\
\hline & Positive & Female & $37.90 \pm 5.28$ & $64.84 \pm 7.01$ bd & $140.00 \pm 14.99$ \\
\hline South-South & Positive & Male & $40.34 \pm 3.05$ & $64.81 \pm 4.05$ bd & $129.33 \pm 8.65$ \\
\hline & Negative & Female & $24.54 \pm 1.78$ & $23.50 \pm 2.36$ a & $115.42 \pm 5.05$ \\
\hline & Negative & Male & $27.10 \pm 1.13$ & $26.54 \pm 1.50$ a & $115.40 \pm 3.21$ \\
\hline & Positive & Female & $34.80 \pm 4.82$ & $47.32 \pm 6.40 \mathrm{bc}$ & $138.17 \pm 13.68$ \\
\hline Test Statistic F-Ratio & Positive & Male & $46.22 \pm 3.15$ & $69.06 \pm 4.19$ de & $136.14 \pm 8.96$ \\
\hline P-value & & 1.3043 & 4.3049 & $0.0140 * *$ & 0.4286 \\
\hline Signicance & $0.2723^{\text {ns }}$ & $0.6517^{\text {ns }}$ \\
\hline
\end{tabular}

Significance Level: $* *=p<0.01 ; n s=$ Not significant $(p>0.05)$, AST $=$ aspartate aminotransferase, $A L T=$ alanine aminotransferase, ALP= alkaline phosphatase.

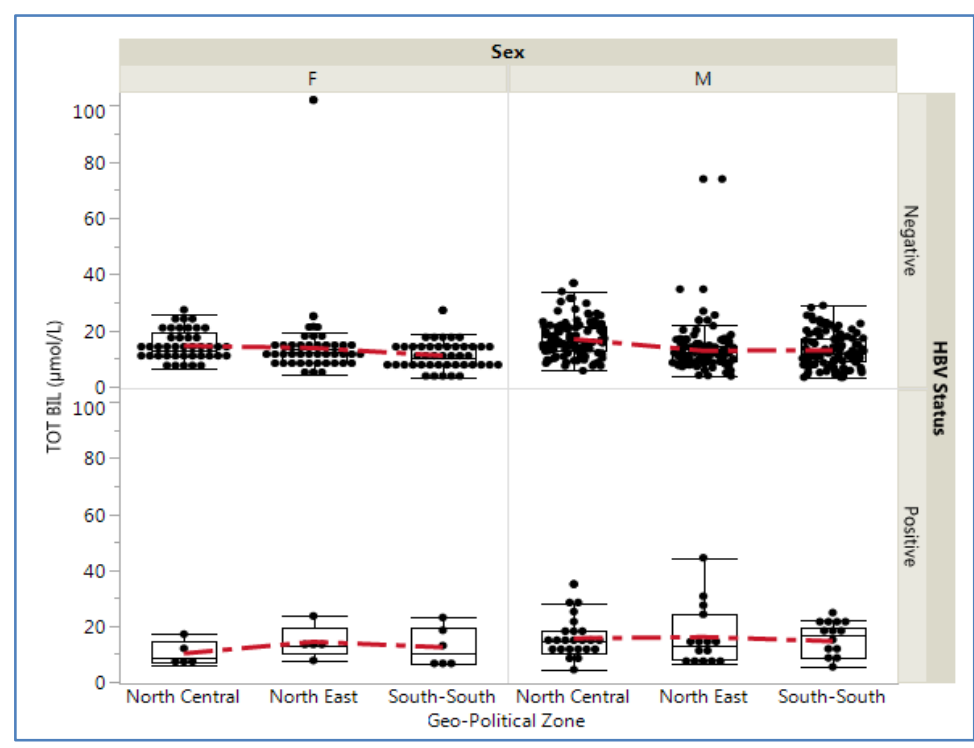

Fig-1: Box Plot of Conjugated Bilirubin by HBV Status and Sex of Volunteer Blood Donors within Geo-Political Zones

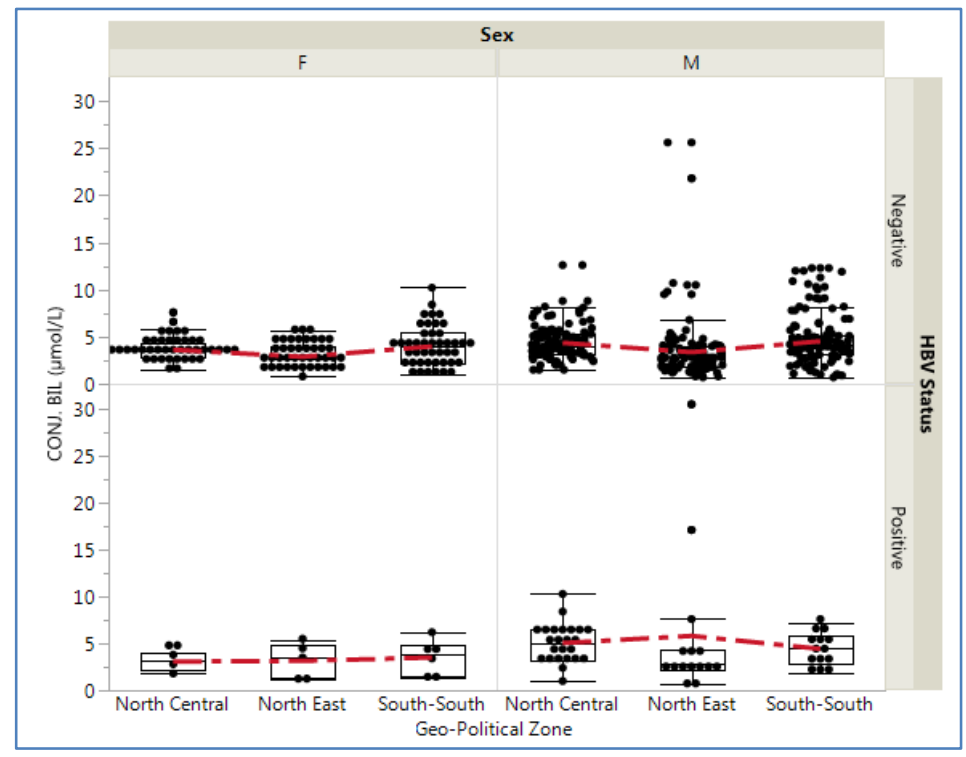

Fig-2: Box Plot of conjugated Bilirubin by HBV Status and Sex of Volunteer Blood Donors within Geo-Political Zones 


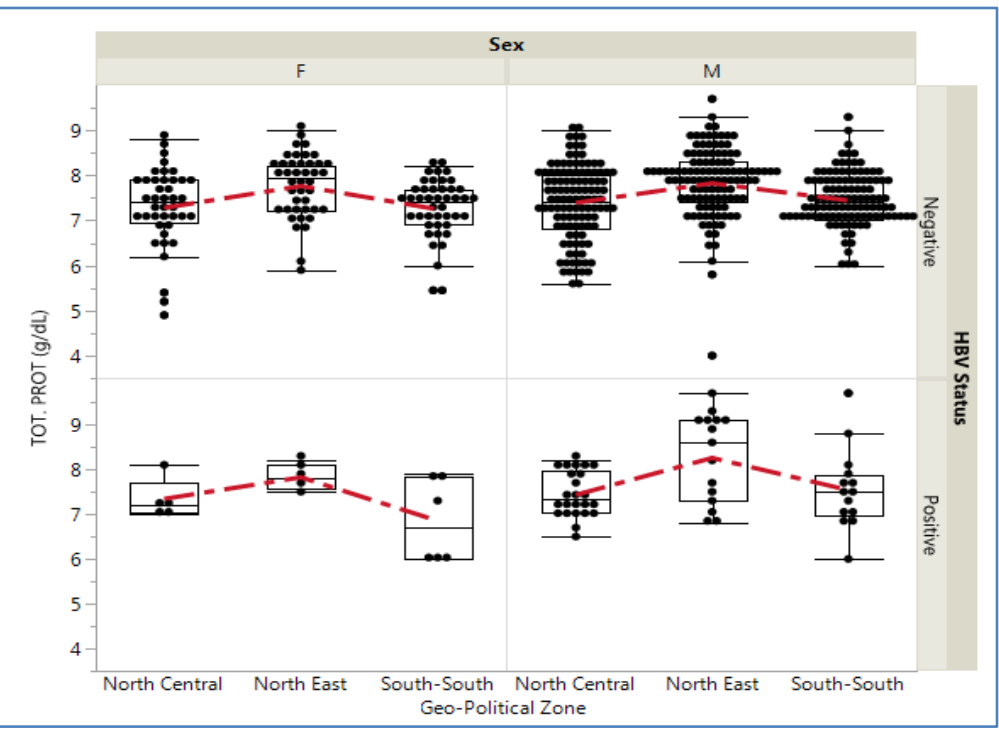

Fig-3: Box Plot of Total Protein by HBV Status and Sex of Volunteer Blood Donors within Geo-Political Zones

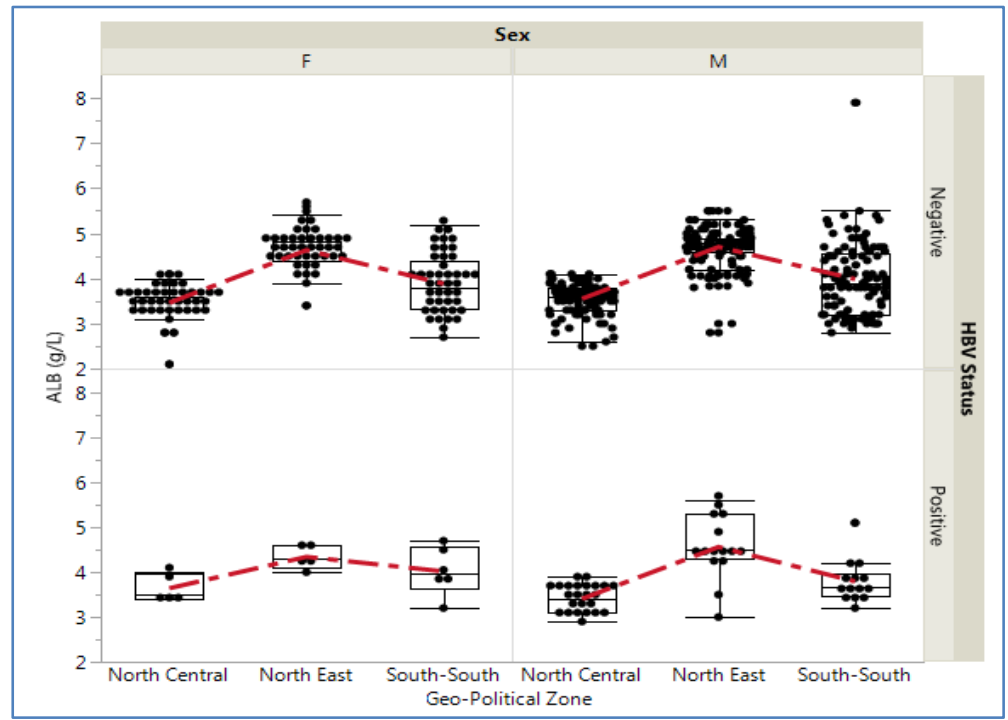

Fig-4: Box Plot of Albumin by HBV Status and Sex of Volunteer Blood Donors within Geo-Political Zones

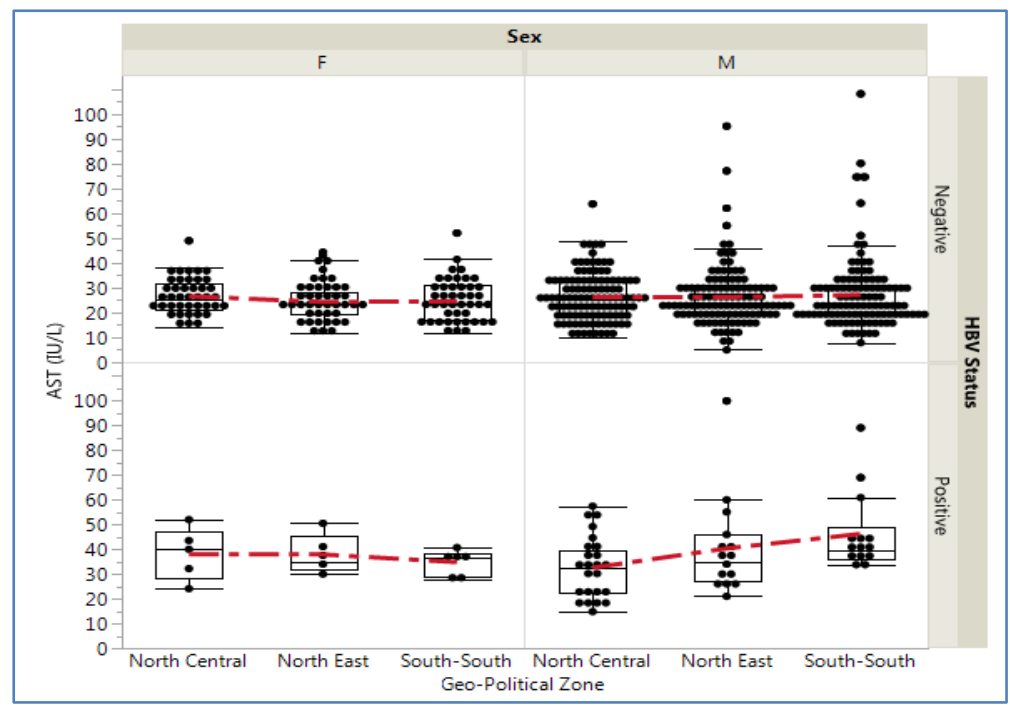

Fig-5: Box Plot of AST by HBV Status and Sex of Volunteer Blood Donors within Geo-Political Zones 


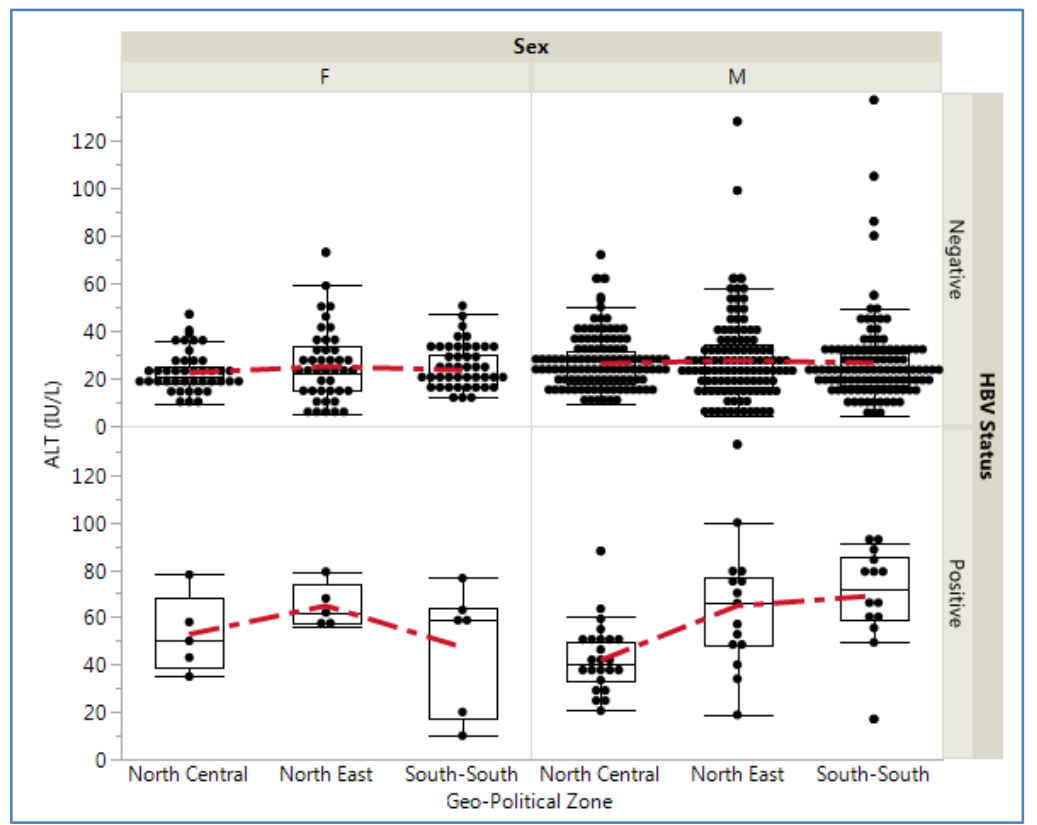

Fig-6: Box Plot of ALT by HBV Status and Sex of Volunteer Blood Donors within Geo-Political Zones

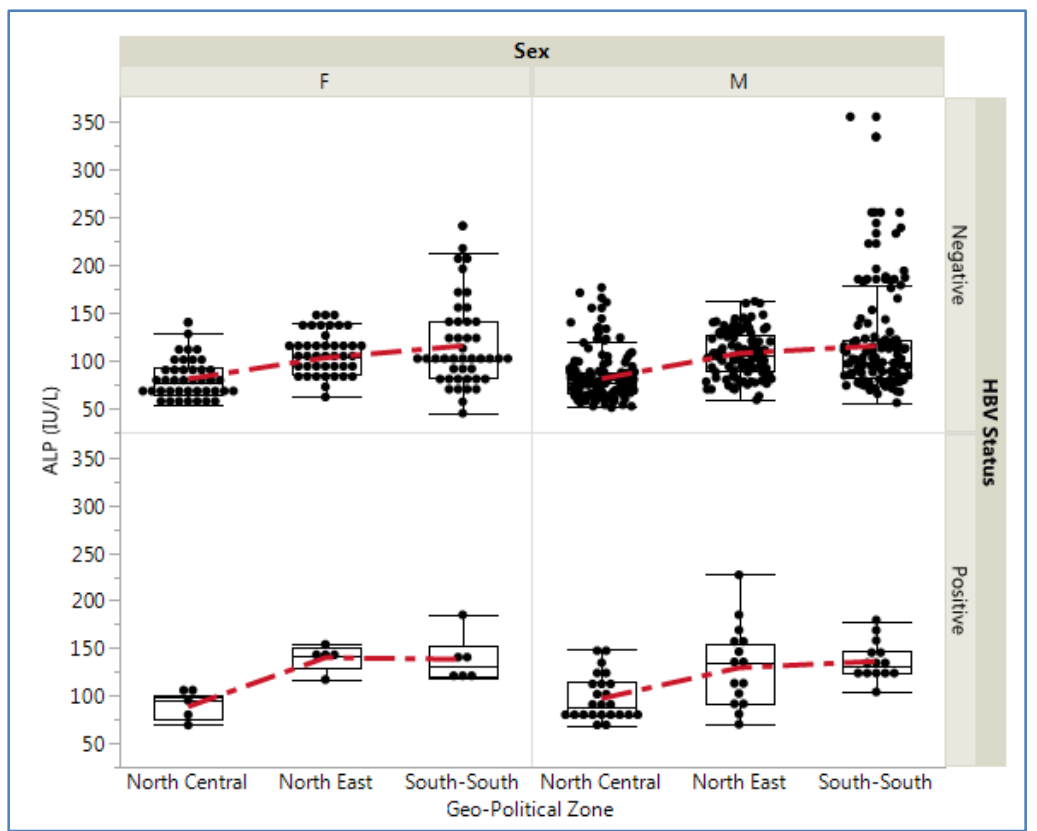

Fig-7: Box Plot of ALP by HBV Status and Sex of Volunteer Blood Donors within Geo-Political Zones

\section{DISCUSSION}

\section{Liver Function Parameters of the Study Population}

Clinically, hepatitis $\mathrm{B}$ virus has been correlated with abnormal levels of metabolites which are synthesized/metabolized in the liver. This study found that the comparism of plasma concentration of total bilirubin in the voluntary blood donors in the three geopolitical zones disaggregated by sex and hepatitis B virus status did not show any significance $(\mathrm{p}=0.8536)$. The reference levels of total bilirubin used was 0-34 $\mu \mathrm{mol} / 1[23]$.

Correspondingly, the comparison of conjugated bilirubin in the geopolitical zones disaggregated by hepatitis B virus status and sex was not significant $(\mathrm{p}=0.06567)$. Mc Mahon (2009) had reported elevated levels of total bilirubin in the icteric phase of acute hepatitis B virus infection, but this study found unchanged plasma bilirubin levels in both HBV negative and positive subjects. This finding agreed with the report of Ganem \& Schneider [15] that in some cases, HBV infection does not manifest as jaundice nor obvious symptoms. According to Pyrsopoulos [29] haemolysis may seldomly occur and may inadvertently results in increased total bilirubin concentration. Bilirubin which is the end - product haem degradation is insoluble in aqueous solution at physiologic $\mathrm{pH}$. It therefore binds to serum albumin and transported to the liver for metabolism and excretion [24]. The Bilirubin is taken up at the sinusoidal membrane in the liver and 
Kingsley Odiabara et al; Sch J App Med Sci, Jan, 2022; 10(1): 34-45

conjugated with glucuronic acid by the enzyme bilirubin diphosphate-glucuronyl transferase in the endoplasmic reticulum. It is thus excreted as water soluble bilirubin glucuronide into the bile [24].

Disturbance of liver function results in ineffective metabolism, consequently leading to increased levels of both conjugated and unconjugated bilirubin [32].

However, we did not observe any abnormality of plasma bilirubin in this study. With respect to total protein parameters, this study found no significant difference in the plasma levels of subjects in the three geopolitical zones, disaggregated by hepatitis $\mathrm{B}$ virus status and sex $(p=0.6145)$. Similarly, the comparison of albumin concentration parameter in the voluntary blood donors across the three geopolitical zones disaggregated by hepatitis $\mathrm{B}$ status and sex was not significant ( $\mathrm{p}=$ $0.4021)$. The reference ranges of total protein and albumin used was 6.4 to $8.3 \mathrm{~g} / \mathrm{dl}$ and 3.5 to $5.2 \mathrm{~g} / \mathrm{dl}$ respectively [23]. The most abundant plasma proteins are proteins secreted by the liver or by B-lymphocytes. For most clinical applications, quantitative changes in specific proteins are the major diagnostic indicator, while in a few cases, qualitative changes evaluated by technique such as electrophoresis serve as diagnostic indicator. Chronic infection often yields a different pattern of plasma proteins than is observed in acute infection. In chronic infection such as hepatitis B virus infection plasma proteins are often increased. However, we relied on our results which did not show any altered pattern of plasma total proteins among the treatment groups, that is, HBV negative and positive subjects. On the other hand, Pyrsopoulos [29] had reported that plasma albumin may slightly decrease in acute hepatitis patients, but our study did not observe any altered levels of albumin.

\section{AST \& ALT}

AST \& ALT are liver enzymes that play important roles in gluconeogenesis. AST transfers amino acid groups from aspartic acid to ketoglutamic acid resulting in oxaloacetic acid. On the other hand, ALT transfers amino groups from alanine to ketoglutaric acid to yield pyruvic acid [27].

ALT is specific to the liver and concentrated in the cytosol, whereas AST can be found in other organs of the body such as heart and muscles tissues and it is found in both cytosol and mitochondria. Hepatic injury result in leakages of ALT and AST leading to elevated serum levels [27, 9]. A plasma AST: AST ratio may help to indicate the type of cell damage.

The aspartate aminotransferase (AST) levels of the voluntary blood donors in the three geopolitical zones disaggregated by hepatitis B virus status and sex were compared. There was no statistically significant difference $(p=0.2723)$. The reference range used was adult male $=<35 \mathrm{u} / \mathrm{L}$; female $=<31 \mathrm{u} / \mathrm{L}$ [23]. On the other hand, the comparism of Alanine aminotransferase (ALT) of the voluntary donors across the three geopolitical zones stratified by the virus and sex was significant $(\mathrm{p}=0.0140)$. The reference interval used was adult male $=<45 \mathrm{u} / \mathrm{L}$; female $=<34 \mathrm{u} / \mathrm{L}$ [23].

Traditionally, liver enzymes are released when there is liver function impairment. Although this study observed an increase in ALT levels, the magnitude of increase contradicts the report of Terrault and colleagues [33] which stated that a 3- to 10- fold to a striking increase of greater than 100 folds is seen in acute phase infection. The results of this study agreed with Panteghini [27] that plasma ALT levels are usually higher than AST in most type of liver disease. The HBV positive subjects in this study were asymptomatic and had no underlining liver disease. The unaltered plasma levels of AST and the marginal increase in ALT levels observed in this study demonstrates the absence of disease process which affects the integrity of liver cells as described by Czuczejke and co researchers [9] and Panteghini [27]. ALT is a cystosolic enzyme with highest activity in the liver, it is therefore more specific marker for hepatocellular disease [27].

The aminotransferase threshold for diagnosing liver injury is a 7- fold increase over the upper reference limit. The results obtained were far below this level; therefore the hepatitis B positive voluntary donors identified in this study were chronic asymptomatic carriers. This study also found a nonsignificance difference in Alkaline phosphatase (ALP) parameter of the voluntary blood donors in the three geopolitical zones, disaggregated by Hepatitis B virus and sex $(\mathrm{p}=0.6517)$. The reference range used was 20 50year male 53-128, female $=42-98 \mathrm{u} / \mathrm{L}$; >60years male $=56-119 \mathrm{u} / \mathrm{L}$ female $=53-149 \mathrm{u} / \mathrm{L}$ [23]. Although enzymes are associated with liver function impairment, the role of ALP is controversial in some studies as reported by Platis [28]. Mastoi and colleagues [20] had implicated an elevated ALP levels in hepatitis B virus infected person, but our study found no such pattern.

ALP activity is present in organs of the body; such as small intestine, proximal tubules of the kidney, bone, liver and placenta, which confer on it non-specific for liver hepatocellular injury such as hepatitis virus infection. Nevertheless, we observed normal ALP levels within the reference range in this study.

\section{Summary \& CONClusion}

Transfusion of blood is intended to correct clinical problems such as blood loss, anaemia, coagulopathies or thrombocytopenia. However, many recipients of blood have been infected with blood borne pathogens such as hepatitis B virus, HIV, and others, transmitted through the transfusion, as a consequence, they later developed diseases which are associated with such pathogens. Great care must 
Kingsley Odiabara et al; Sch J App Med Sci, Jan, 2022; 10(1): 34-45

therefore be taken to ensure the quality and safety of blood products. Moreover, transfusion of blood should be given for a good reason after evaluation of the patient's clinical situation.

This study assessed the effect of hepatitis b virus on liver function parameters in voluntary blood donors who tested positive to the virus. The study did not identify any abnormality in plasma levels of liver function parameters of the subjects. The asymptomatic HBV carriers were apparently healthy.

\section{Limitations of the study}

This study was carried out on voluntary blood donors in towns within three geopolitical zones. Thus, the findings may not be generalizable to all populations.

We were not able to identify the occupational status of the study population. Therefore, more prospective research studies are needed to further validate the association of hepatitis $B$ virus infection and socio-demographic factors.

This study also had limitation of inability to follow up the hepatitis B virus seropositive subjects for likely complications over time, due to paucity of time and limited resources.

\section{ACKNOWLEDGMENT}

The authors are grateful to participants who agreed to take part in this study.

\section{Funding} this study.

No external funding support was received for

\section{Conflict of interest}

None to declare

\section{REFERENCES}

1. Asinal, E.J., Hawkins, G., Fraser, A., Hutchinson, S.J., \& Golberg, D. (2011). Hepatitis B prevention, diagnosis, treatment and care: a review occupational medicine (lond), 61(18), 531-540.

2. Awareness, T. (2008). Chemwell 2910 Automated EIA and Chemistry Analyzer Manual. Awareness Technology Inc. 2325 SW Martin Hwy, Palm City, FL 34990, USA, 1, 21-24.

3. Bio-Rad. (2013). Monolisa HBs Ag ultra-kit for the detection of the surface antigen of the Hepatitis B virus in human serum or plasma by enzyme immunoassay. Bio-Rad 92430 Marnes-la-CoquetteFrance.

4. Busch, M.P., Bloch, E.M., \& Kleinman, S. (2019). Prevention of transfusion transmitted infections. Blood, 133(17) 1854-1864

5. Chapman, R., Fevevy, J., Kalloo,, A., Nagomey, D.M., Bobevg, K.M., Shneider, B., \& Gores, G.J.
(2010). Diagnosis and Management of primary Sclerosing cholangitis. Hepatology, 51; 660 - 78

6. Charan, J., \& Biswas, T. (2013). How to Calculate Sample Size for Different Study Designs in Medical Research. Indian Journal of Psychological Medicine, 35(2); 121-126

7. Chen, D. S. (2009). Hepatitis B vaccination. The key towards elimination and eradication of Clinicopathological study in 14 children". Paediatric Nephrology, 18(1), 23-28.

8. Crook, M.A. (2012). Clinical Biochemistry and metabolic medicine $8^{\text {th }}$ Edition. Hodder Arnold, London, United Kingdom, 255

9. Czuczejke, J., Zachara, B. A, Staubach Topczewska, E., Halota, W., \& Kedziora, J. (2003). Selenium, glutathione and glutathione peroxidases in blood of patients with chronic liver diseases. Acta Biochimica Polonica, 50, 1147- 1157.

10. Dean, C. L., Wade, J., \& Roback, J.D. (2018). Transfusion-Transmitted Infections: an update on Product Screening, Diagnostic Technique and the path ahead. Journal of Clinical Microbiology, 56(7); eoo352-18

11. Dia-Pro. (2015). HCV Ab version 4.0 Enzyme immunoassay for the determination of antiHepatitis $\mathrm{C}$ virus anti-body in human serum and plasma. DIA-PRO Diagnostic Bio probes Sri 20099 Sesto San Giovanni (Milano)-Italy.

12. Dufour, D. R. (2015). Liver Disease: In Tietz Fundamentals of clinical chemistry and Molecular Diagnostics $7^{\text {th }}$ edn. Saunders Elsevier, Missouri, USA. Pp

13. Fattovich, G., Bortolotti, F., \& Donato, F. (2008). Natural history of chronic HBV, special emphasis on disease progression and prognostic factor. Journal of Hepatology, 48, 335- 352.

14. FMoH, (2016). Guidelines for the prevention, Treatment and care of viral hepatitis in Nigeria. NASCP, Federal Ministry of Health, Abuja.

15. Ganem, D., \& Schneider, M. (2001). Hepadnaviridae: the viruses and their replication. In: Knipe DM \& Howley, PM. Fields Virology. Lippincott-Raven. Philadelphia, 2923-2970.

16. Hollinger, F. B., \& Liang, T. J. (2001). Hepatitis B virus In: Knipe D.M fields virology. $4^{\text {th }}$ edn Lippincott Williams \& Wilkins, Philadelphia Pp 2971-3036

17. Levinson, W. (2014). Review of Medical Microbiology and Immunology, 13th edn. McGraw Hill Education, Lange, New York, USA.

18. Lozano, R., Naghavi, M., Foreman, K., Lim, S., Shibuya, K., \& Abonyans, V. (2012). Global and regional mortality from 235 causes of death for 20 age groups in 1990 and 2010 and systematic analysis for the global Burden of Diseases study 2010. Lancet, 380(9859), $2095-2128$

19. Maini, M.K., Lee, C.K., Lamubia, J.R., Reghat, S., Ogg, G.S., King, A.S., Herber, G.J., Gilson, R., Alisa, A., Williams, R., Vergani, D., Naoumov, N.V., Ferraric., \& Bertoletti, A. (2000). The Role 
Kingsley Odiabara et al; Sch J App Med Sci, Jan, 2022; 10(1): 34-45

of virus - Cd8t cells in liner damage and viral control during persistent hepatitis B virus infection. The Journal of Experimental Medicine, 19(8); 1269 $-1292$

20. Mastoi, A. A., Devrajani, B. R., Shah, S. Z. A., Rohopoto, Q., Memon, S. A., Balooh, M., Qureshi, G. A., \& Sami, W. (2010). Metabolic investigations in patients with hepatitis B and C. World Journal of Gastroenterology, 16(5), 603-607.

21. McMahon, B. J. (2004). The natural history of chronic hepatitis B virus infection. Seminar on Liver Diseases, 24(1), $17-12$.

22. McMahon, B. J. (2009). The natural history of chronic hepatitis B virus infection. Hepatology, 49(5), 545-555.

23. McMillin, G. A., Burtis, C. A., \& Bruns, D. E. (2015). Reference Information for the Clinical Laboratory. In: Tietz Fundamentals of Clinical Chemistry and Molecular Diagnostics $7^{\text {th }}$ Edition. Saunders Missouri USA, 951-992

24. Ochei, J., \& Kolhatker, A. (2007). Medical Laboratory Science: Theory and Practice. $6^{\text {th }}$ edn. McGraw Hill Company Ltd. New Delhi, India.

25. Ott, J. J., Stevens, G. A., Groeger, J., \& Wiersma, S. T. (2012). Global epidemiology of hepatitis B virus infection: New estimates of age -specific HBs Ag Seroprevalence and endemicity. Vaccine, (12), $2212-2219$

26. Pan, C.Q., \& Zhang, J.X. (2005). Natural history and clinical consequences of Hepatitis B virus infection. International Journal of Medical Sciences, 2(1); 36-40

27. Panteghini, M. (2015). Serum Enzymes. In Tietz Fundamentals of Clinical Chemistry and Molecular Diagnostics. $7^{\text {th }}$ edition. Saunders, Missour. USA., 322-325.
28. Platis, O., Anagnostopoulos, G., Farmakik, Posantzis, M., Gotsis, E., \& Tolis, G. (2004). Glucose Metabolism disorders improvements in patients with thalassaemia major after 24- 36 months of intensive chelation therapy. Paediatric Endocrinological Reviews. 2 Suppl, 2, 279- 281.

29. Pyrsopoulos, N. (2016). Hepatitis B: History, pathogenesis, chinical manifestation, Diagnostic workup, Laboratory Diagnosis, Treatment and Prevention. A publication of State University, New Jersy. The RUTGERS-NJMS, Neward NJ 07101

30. Shi, Y.X., Huang, C.J., \& Yang, Y.G. (2016). Impact of hepatitis B virus infection on hepatic metabolic signalling pathway. World Journal of Gasteroenterology, 22(36); 8161 - 8167.

31. Souza, R., \& Foster, G. R. (2004). Diagnosis and treatment of chronic hepatitis B, Journal of the Royal Society of Medicine, 97, 318-321.

32. Tabansi, P.N., Akinwumi., \& Animashuan, A.B. (2016). Pathophysiology of some Laboratory parameters useful in the Diagnosis of Cardiovascular System Disorders: In Nkanginiene K.E.O, Ohaeri J.U, Durosimi M.A., Shokumbi, T., \& Ugwu, R. (2016). Pathophysiology of Clinical Systoms, signs \& Laboratory parameters. Athena Academic Ltd London, United Kingdom, 398-399

33. Terrault, N. A., Bzowei, N. H., Chang, K. M., Hwang, J. P., Jonas, M. M., \& Murad, M. H. (2015). AASLD Guidelines for Treatment of chronic Hepatitis B, Hepatology, 00(00), 1-23.

34. World Health Organization. (2015). Guidelines for the prevention, care and treatment of Persons with chronic hepatitis B infection. Geneva, Switzerland.

35. World Health Organization. (2018). Hepatitis B. Fact Sheet. http://www,who.int/news-room/factsheets/details/hepatitis-b 